\title{
Exploration of New Pathways in Oncology
}

\section{Simon Raymond*}

\section{Alumnus, Melbourne University, Australia}

*Corresponding Author: Simon Raymond, Alumnus, Melbourne University, Australia.
Received: July 11, 2020

Published: August 26, 2020

(C) All rights are reserved by Simon

Raymond.
To date, immunization has consisted of two principle pathways: (1) replication of infective agent; (2) enhancement of immune function. Given the lack of Success of the two current pathways, the current researcher (author) has conceptualised (developed) the new, or third, pathway of site attachment inhibition. The methodology surrounding site attachment inhibition therapeutics has been discussed in previous lectures [1-9]. It involves both medication based treatment of established infections and preventative immunization (new generation; stem cell therapy based).

New generation immunization involves stem cell therapy (including mutagenesis and knockout) of particular genetic targets such to achieve immunity (resistance) to infectious agents that is similar to what occurs with hereditary genetic variations/mutations).

An example provided was with HIV and the CCR5-delta32.

CRISPR has been discussed however the researcher reiterates that it can be any knockout/mutagenesis technique used. It is not reliant on CRISPR.

One key is ensuring association versus causation issues are dealt with in identifying the genes.

The importance to Oncology is now drawn

Gardasil is an immunization that utilises Pathway 2 above which as a conjoined benefit prevents cervical cancer.

It is therefore interesting to consider whether Pathway 3 through similar methods to the new generation immunization discussed could similarly be explored as preventative treatment for cancers. It is further interesting that preventing HIV (E.g. as detailed in lectures on stc based immunization) may in some respects prevent certain Kaposi's Sarcoma.

\section{Summary}

This lecture details site attachment inhibition with a focus on new generation immunization. The lecture explains that immunology is actually of interest to oncology. Specifically, Gardasil utilises Pathway 2 and by way of preventing infectious disease also prevents cervical cancer. The lecture then presents why it would be perhaps worth exploring whether Pathway 3 could also be explored in Oncology for successful treatment (preventative) of cancer.

In conclusion, the focus of Pathway 3 perhaps should not only be regarding immunization but also treatment (preventative) for cancer.

\section{Bibliography}

1. Raymond S. 6th International Conference and Expo on Immunology (870th Congress) Oct 24-26, Chicago, IL, USA (2016).

2. Raymond S. Annual Conference on Microbial Pathogenesis, Infectious Disease, Antimicrobials and Drug Resistance Aug 2324, Toronto, Canada (2017).

3. Raymond S. "Development of New Strategic Pathways for Antiviral Therapy". Journal of Clinical and Cellular Immunology 7 (2016): 5.

4. Raymond S. "Consciousness and the Development of New Strategic Pathways for Antiviral Therapy A Focused Analysis on HIV". International Journal of Sciences: Basic and Applied Research (IJSBAR) 29 (2016): 146-154. 
5. Raymond S. "The Development of New Antimicrobial Pathways Combatting the Threat of Antimicrobial Resistance". International Journal of Sciences: Basic and Applied Research (IJSBAR) 30 (2016): 22-28.

6. Raymond S. "Site Attachment Inhibition Therapeutics: A Core Summary”. Journal of Aids and Clinical Research 8 (2017): 664.

7. Raymond S. 12th World Congress on Pharmaceutical Sciences and Pharma Industries, Site Attachment Inhibition Therapeutics: Dealing with Association versus Causation Issues, February 26-27, London, UK (2018).

8. Raymond S. 10th International Conference on Clinical and Cellular Immunology, Site Attachment Inhibition Therapeutics: Dealing with Association versus Causation Issues, August 06-07, Madrid, Spain (2018).

9. Raymond S. "Site Attachment Inhibition and the Application of Quantum Physics to Medicine and Surgery". Journal of $\mathrm{Hu}$ man-Social Science (IOSR-JHSS) 23.1( 2018): 8-12.

\section{Assets from publication with us}

- Prompt Acknowledgement after receiving the article

- Thorough Double blinded peer review

- Rapid Publication

- Issue of Publication Certificate

- High visibility of your Published work

Website: www.actascientific.com/

Submit Article: www.actascientific.com/submission.php

Email us: editor@actascientific.com

Contact us: +919182824667 